\title{
POTENSI DAUN SERAI SEBAGAI TERAPI KOMPLEMENTER PADA SELULITIS
}

\author{
Nursilri Meidania*'Jihan Nur Pratiwi \\ Fakultas Kedokteran, Universitas Lampung, J1. Prof. Dr. Ir. Sumantri Brojonegoro No.1, Gedong \\ Meneng, Kec. Rajabasa, Kota Bandar Lampung, Lampung, Indonesia 35145 \\ *nmeidania@gmail.com (+6281297552800)
}

\begin{abstract}
ABSTRAK
Selulitis merupakan penyakit infeksi yang terjadi di kulit, baik itu dermis maupun jaringan subkutan. Gejala klinis yang muncul dapat berupa gejala akut yaitu eritema, nyeri, edema, inflamasi supurasi, serta gejala sistemik berupa malaise, demam, menggigil, dan nyeri lokal. Penyebab utama selulitis yaitu bakteri kokus gram positif seperti Streptococcus spp. atau Staphyloccocus aureus. Serai mengandung antimikroba dan antiinflamasi yang baik untuk membantu mengatasi selulitis. Tujuan dari tinjauan pustaka ini adalah untuk melaporkan temuan ilmiah terbaru tentang peran kandungan Serai dalam menngatasi selulitis dengan kandungannya yang dapat menghambat pertumbuhan bakteri penyebab selulitis dan meredakan gejala peradangan dengan sifat antiinflamasinya. Metode yang digunakan dalam artikel berjenis tinjauan pustaka ini adalah literature searching method melalui database NCBI dan Google Scholar. Tahun penerbitan sumber pustaka adalah dari tahun 1999 sampai tahun 2019 dengan 21 sumber pustaka dan 11 sumber yang digunakan dalam menjelaskan mekanisme kandungan Serai. Tema yang dikumpulkan terkait dengan kandungan Serai dalam mengatasi selulitis. Hasil dari sintesis artikel yang telah ditemukan yaitu serai bermanfaat dalam mengatasi selulitis.
\end{abstract}

Kata kunci: antimikroba, daun serai, selulitis

\section{THE POTENTION OF LEMONGRASS AS COMPLEMENTER THERAPY IN CELLULITIS}

\begin{abstract}
Cellulitis is an infectious disease that occurs in the skin, both skin and subcutaneous tissue. Clinical symptoms that appear can be in the form of acute symptoms such as erythema, pain, edema, inflammation suppuration, and systemic symptoms consisting of malaise, fever, chills, and local pain. The main cause of cellulitis is gram-positive cocci such as Streptococcus spp. or Staphyloccocus aureus. Lemongrass contains antimicrobial and anti-inflammatory which is good for helping to overcome cellulitis. The purpose of this literature assessment is to report the latest scientific findings about the role of collection. The method used in this article is a literature search method through the NCBI database and Google Scholar. The year of library resource contributions is from 1999 to 2019 with 21 library sources and 11 sources used in describing the Serai Theme resources collected related to Serai content in overcoming cellulitis. The results of the synthesis of articles that have been found that Lemongrass is useful in overcoming cellulitis.
\end{abstract}

Keywords: antimicroba, cellulitis, lemongrass

\section{PENDAHULUAN}

Selulitis secara sederhana didefinisikan sebagai infeksi akut pada kulit yang melibatkan dermis dan jaringan subkutan (Sullivan dan Bara, 2018). Selulitis adalah infeksi pada dermis dalam dan jaringan subkutan, disertai 
dengan eritema yang luas, hangat, dan bengkak (JAMA, 2016).

Selulitis relatif umum, dan paling sering terjadi pada orang dewasa dan lanjut usia. Antara pria dan wanita tidak ada perbedaan yang signifikan secara statistik dalam kejadian selulitis insidensi selulitis 2 diperkirakan 24,6 kasus per 1.000 pasien pertahun. Mcnamara, 2007. Didapatkan kasus selulitis sebanyak 48 kasus $(1,4 \%)$ pada RSUD Dr. Soetomo Surabaya tahun 2008-2011 Berdasarkan jenis kelamin dan jumlah pasien, selulitis lebih banyak diderita oleh laki-laki bila dibandingkan perempuan dengan rasio 1,2:1 (36 pria banding 29 wanita) dengan kelompok usia terbanyak ditemukan pada 45-65 tahun $(35,4 \%)$ (Novarina, 2015).

Selulitis biasanya muncul sebagai area eritema yang akut, menyebar, dan berbatas tidak tegas. Temuan kulit pada selulitis mengikuti tanda klasik peradangan yakni dolor (nyeri), kalor (panas), rubor (eritema), dan tumor (pembengkakan). Gambaran klinis lainnya yaitu edema dan pelebaran limfatik kulit yang menyebabkan penampilan peau d'orange (seperti kulit jeruk), terbentuknya bula, atau limfangitis (Borschitz, 2015).

Penyebab utama selulitis yaitu bakteri kokus gram positif seperti Streptococcus spp. atau Staphyloccocus aureus (Benneth et al., 2010). Selulitis pada orang dewasa yang imunokompeten biasanya diduga disebabkan oleh streptokokus grup A (Streptococcus pyogenes), dengan Staphylococcus aureus sebagai penyebab utama tetapi kurang umum (Steven et al., 2014).
Faktor resiko terjadinya selulitis yang paling umum adalah edema, terutama lymphedema karena cairan limfatik dianggap memfasilitasi pertumbuhan bakteri. Faktor lain seperti usia, obesitas, insufisiensi vena, tinea pedis, trauma, dermatitis, dan lainnya (Pavlotsky, 2004).

Tatalaksana selulitis dibagi menjadi dua. Pasien dengan infeksi kulit dan jaringan lunak purulen seperti abses harus mengambil sampel melalui insisi dan drainase. Sampel digunakan untuk biakan bakteri dan pertimbangan pemberian antibiotik pada pasien dengan tanda infeksi sistemik. Infeksi kulit dan jaringan lunak non-purulen umumnya memerlukan pengobatan dengan antimikroba sistemik. Terapi antimikroba oral cukup untuk pasien tanpa tanda infeksi sistemik dan tanpa komorbiditas (selulitis derajat I), beberapa pasien selulitis derajat II diberikan antibiotik oral atau terapi awal intravena (IV) baik di rumah sakit atau melalui rawat jalan. Agen intravena harus digunakan untuk mereka yang memiliki bukti infeksi sistemik (selulitis kelas III dan IV) atau mereka yang tidak berespon terhadap terapi oral awal. Pasien dengan infeksi yang dalam atau nekrosis harus melakukan konsultasi bedah segera untuk pertimbangan debridemen (Stevens et al., 2014).

Pengetahuan secara ilmiah tentang metabolit meningkat dengan adanya pencarian agen terapeutik baru dari sumber tanaman yaitu metabolit sekunder yang merupakan sumber utama zat bioaktif, hal ini disebabkan karena perkembangan resistensi mikroorganisme penyebab penyakit meningkat terhadap sebagian besar obat antimikroba yang saat ini digunakan (Mbosso et al., 2010). Untuk itu diperlukan tinjauan mengenai 
penggunaan tanaman sebagai terapi tambahan pada tatalaksana farmakologis.

Salah satu sumber tanaman yang mengandung antibakterial adalah Serai. Serai atau Cymbopogon citratus adalah salah satu herbal yang paling umum digunakan dalam pengobatan tradisional karena sifatnya anti-inflamasi dan antioksidan karena mengandung kaya akan senyawa fenolik berupa flavonoid dan tannin (Garcia et al., 2015). Selain itu telah terdapat beberapa studi yang menyebutkan pula bahwa Serai memiliki sifat antiamuba, antibakteri, antidiare, antifilaria, dan antijamur yang berkaitan dengan minyak atsiri yang mengandung Citral $\alpha$, Citral $\beta$, Nerol Geraniol, Citronellal, Terpinolene, Geranyl acetate, Myrecene dan Terpinol Methylheptenone pada Serai (Shah et al., 2011). Adapun tujuan tinjauan pustaka ini dilakukan adalah untuk mengetahui manfaat kandungan Serai sebagai terapi komplementer pada Selulitis.

\section{METODE}

Metode yang digunakan adalah literature searching. Sumber pustaka yang digunakan dalam artikel ini berjumlah 21 pustaka dan 11 jurnal yang dipakai dalam menjelaskan manfaat dan mekanisme Serai sebagai antiinflamasi dan antimikroba serta beberapa manfaat lainnya yang bermanfaat terhadap selulitis, baik yang berasal dari buku, jurnal nasional atau internasional, maupun website. Penelusuran sumber pustaka dalam artikel ini melalui database NCBI dan Google Scholar dengan kata kunci Antimicroba, Cellulitis, Lemongrass. Pemilihan artikel sumber pustaka dilakukan dengan melakukan peninjauan pada judul dan abstrak yaitu membahas tentang potensi Serai dalam mengatasi selulitis. Tahun penerbitan sumber pustaka dalam penulisan artikel ini adalah 1999 hingga tahun 2019.

\section{HASIL}

Menurut beberapa penelitian yang didapatkan, kandungan pada Serai dapat bermanfaat terhadap selulitis, diantaranya memiliki berbagai aktivitas farmakologi seperti antimikroba, antiinflamasi, antifungal, dan antioksidan (Shah, Richa, Vivek et al., 2011).

Perannya sebagai antimikroba yaitu memiliki menghambat pertumbuhan bakteri gram positif dan gram negatif seperti diantaranya yaitu Staphylococcus aureus dan Candida albicans yang memiliki nilai hambat sebesar 0,06\% (Hammer et al., 1999. Adapun menurut penelitian Silva et al., daya hambat dan bakterisidal minyak Serai berpengaruh terhadap bakteri Salmonella enterica, Proteus mirabilis, Citrobacter freundii, Aeromonas hydrophila sebesar 0,016 hingga 0,5\% (Silva et al., 2017).

Sementara pada penelitian Naik et al., mengungkapkan bahwa minyak Serai justru efektif terhadap bakteri gram positif dibandingkan gram negatif. Pada studi yang dilakukannya, Pseudomonas aeruginosa memiliki resistensi yang tinggi, sementara pada $S$. aures dan $B$. cereus didapatkan sangat sensitif dan Serai memiliki daya hambat sebesar $0,03 \%$ dan $0,6 \%$ pada keduanya. Pada bakteri B. Subtilis dan E. Coli dapat dihambat pada konsentrasi sebesar $0,06 \%$ dan $0,12 \%$ (Naik et al., 2010)

Hal ini dapat bermanfaat dalam menghambat bakteri penyebab selulitis yaitu bakteri kokus gram positif seperti Streptococcus spp. atau Staphyloccocus aureus (Benneth et al., 2010). Selain itu 
Serai mengandung senyawa lain yaitu terpene hidrokarbon, alkohol, keton, ester dan terutama aldehida. Minyak atsiri pada Serai $(0,2-0,5 \%)$ terdiri dari citral. Citral adalah campuran dua aldehida stereoisomerik monterpene; isomer trans geranial (40-62\%) dan isomer cis neral (25-38\%) (Rauber et al., 2005).

Kandungan tersebut, terutama citral, berperan sebagai antiinflamasi yang bermanfaat terhadap peradangan yang menjadi tanda klinis pada selulitis. Kandungan fenolik yaitu tanin dan flavonoid yang dikandung bermanfaat mengurangi edema dengan mekanisme menghambat sintesis dan pengeluaran media inflamasi dan aktivitas antioksidannya, seperti penelitian yang dilakukan oleh Figueirinha et al., dimana edema pada kaki tikus yang diinduksi Carrageenan dapat berkurang dengan pemberian infus daun Serai dengan presentasi hambatan edema sebesar 70.80 and $82.30 \%$ (Figueirinha et al., 2010).

Citral juga telah dilaporkan dapat menekan tumor necrosis factor (TNF)- $\alpha$ yang diinduksi neutrofil pada konsentrasi 0,1\% (Cassia, 2013). Selain itu, Citral dapat menghambat induksi nitric oxide synthase (iNOS), produksi nitric oxide (NO) dan jalur lain yang diinduksi lipopolisakarida (LPS), dan menghambat peradangan jaringan secara oral dan topikal (80-90\%) (Oladeji, 2019).

\section{PEMBAHASAN}

Selulitis merupakan penyakit infeksi yang terjadi di kulit, baik itu dermis maupun jaringan subkutan. Gejala klinis yang muncul dapat berupa gejala akut dan gejala sistemik. Gejala akut yaitu eritema, nyeri, edema, inflamasi supurasi pada kulit, jaringan lemak subkutan, atau otot dan gejala sistemik berupa malaise, demam, menggigil, dan nyeri lokal (Lipworth et al., 2012).

Selulitis paling sering disebabkan oleh bakteri, pada dewasa yaitu Staphylococcus aureus dan Streptokokus beta hemolitikus grup A sedangkan pada anak yaitu Haemophilus influenza tipe $b$ (Hib), Streptokokus beta hemolitikus grup A, dan Staphylococcus aureus. Pada dewasa yang mengalami gangguan imunitas, biasa disebabkan oleh Streptococcus pyogenes dan Staphylococcus aureus (Concheiro et al., 2009).

Menurut derajat keparahannya, selulitis diklasifikasikan menurut modifikasi Dundee yaitu; pada derajat satu, tidak ada atau terdapat komorbiditas yang terkontrol, kondisi sistemik baik, tidak ada sepsis, dan standar nilai peringatan awal atau SEWS <4. Derajat dua, komorbiditas tidak terkontrol namun keadaan sistemik baik ataupun sebaliknya, tidak terdapat sepsis, SEWS $<4$. Derajat tiga, terdapat respon inflamasi atau komorbiditas tidak terkontrol, sepsis, namun SEWS <4. Derajat empat, syok sepsis dengan SEWS lebih dari sama dengan 4 (Sullivan et al., 2014).

Diagnosis selulitis didasarkan pada anamnesis dan pemeriksaan klinis. Anamnesis berdasarkan keluhan pasien berupa keluhan lokal peradangan dan gejala prodormal, pemeriksaan fisik selulitis didapatkan makula eritematous, tepi tidak tinggi, batas tidak jelas, edematosa, infiltrat, teraba hangat, disertai limfangitis atau limfadenitis. Penderita biasanya demam dan dapat menjadi septikemia. Pada pemeriksaan darah tepi terdapat leukositosis (15.000- 
400.000) dengan hitung jenis shift to the left (Wolff et al., 2008).

Selulitis yang disebabkan oleh bakteri streptokokus dapat diberikan tatalaksana farmakologi Penisilin prokain $\mathrm{G}$ dengan dosis 600 ribu-2 juta IU secara intramuskular selama 6 hari, atau penisilin V $500 \mathrm{mg}$ secara oral setiap 6 jam selama 10-14 hari. Pada selulitis yang disebabkan oleh $\mathrm{H}$. Influenza diberi Ampicilin untuk anak usia 3 bulan-12 tahun dengan dosis 100$200 \mathrm{mg} / \mathrm{kg} / \mathrm{hari}$ (150-300 mg), usia >12 tahun menggunakan dosis dewasa. Pada pasien dengan alergi penisilin dapat menggunakan eritromisin dengan dosis dewasa yaitu 250-500 gram peroral dan anak-anak: 30-50 mg/kgbb/hari, setiap 6 jam selama 10 hari. Atau Klindamisin dengan dosis dewasa 300-450 mg/hari peroral dan anak-anak 16-20 $\mathrm{mg} / \mathrm{kgbb} / \mathrm{hari}$. (Concheiro et al., 2009).

Dalam mengatasi selulitis, selain pengobatan menggunakan antibiotik, juga diperlukan pengobatan komplementer dari bahan tanaman yang sedikit memiliki efek samping. Adapun salah satu tanaman yang berpotensi yaitu Serai.

Serai (Cymbopogon citratus) termasuk ke dalam keluarga rerumputan (Poaceae), nama lainnya yaitu Lemongrass karena memiliki aroma seperti jeruk lemon. Tanaman ini tumbuh dalam rumpun subur dan dapat mencapai tinggi dan lebar 1-1,8 m. Bilah daun sekitar 18-36 cm dengan venasi paralel. Tidak menghasilkan bunga. Tanaman ini tumbuh dalam rumpun subur dan dapat mencapai tinggi dan lebar 1,8 $\mathrm{m}$ dan 1,2 m. Bilah daun sekitar 18-36 cm dengan venasi paralel dan karakteristik jatuh mencolok. Mereka tidak menghasilkan bunga atau malai (kultivar).
Perbungaannya sekitar 30-60cm dengan ras berpasangan-memungkinkan untuk perbungaan parsial. Daun seperti tali memiliki lebar sekitar 1,3-2,5cm, panjang $0,9 \mathrm{~cm}$ dengan aroma jeruk karena mengandung citral dan banyak aldehida geranial (Tajidin et al., 2011).

Serai mengandung minyak esensial seperti $\alpha$-sitral (geranial) dan $\beta$-sitral (neral) telah diisolasi, dikarakterisasi dan dianalisis dari daunnya. Senyawa ini adalah antibakteri aktif. Dalam pengobatan tradisional, tanaman tersebut telah digunakan untuk memerangi infeksi bakteri seperti salah satunya selulitis (Soares, 2013).

Hal ini juga dijelaskan dalam penelitian Barbosa et al., bahwa minyak atsiri yang dikandung Serai memiliki tiga komponen komposisi utama, yaitu: alpha citral (geranial), beta-citral (neral) dan myrcene. Studi ini menunjukkan bahwa alfa dan beta sitral memiliki aktivitas antimikroba terhadap bakteri Gram-positif dan Gram-negatif. Namun, komponen myrcene tidak menunjukkan aktivitas antimikroba jika berdiri sendiri. Adapun evaluasi konsentrasi dan komposisi kimia minyak atsiri yang diperoleh dari 12 sampel Serai yang berbeda, ditemukan senyawa lain yaitu: neral, geranial, limonene, citronellal, myrcene, dan geraniol (Barbosa et al., 2008).

Efek minyak atsiri pada Serai berpengaruh terhadap mikroorganisme seperti Acinetobacter baumannii, Aeromonas veronii, Candida albicans, Enterococcus faecalis, Escherichia coli, Klebsiella pneumoniae, Pseudomonas aeruginosa, Salmonella enterica, Serratia marcescens aureus. Hal ini dijelaskan dalam penelitian Hammer, bahwa ditemukan aksi antimikroba yang signifikan dari minyak Serai untuk 
semua organisme yang dianalisis di atas dilihat dari konsentrasi daya hambatnya. Minimum inhibitory consentration (MIC) minyak atsiri Serai adalah $0,06 \%$ untuk S. aureus dan C. albicans (Hammer et al., 1999).

Selain itu, kandungan lain pada Serai yaitu CcI, polifenol, tanin, dan flavonoidnya, terutama luteolin, cassiaoccidentalin, carlinoside dan cynaroside, bermanfaat sebagai efek antiinflamasi topikal. Polifenol ini bisa menjadi bahan aktif sebagai agen antiinflamasi yang efektif untuk pengobatan patologi terkait peradangan pada kulit. (Costa, 2015).

Citral yang diekstraksi dari Serai dapat menghambat mediator inflamasi dan berfungsi sebagai aditif dalam krim dan salep untuk mengobati peradangan topikal. Citral juga telah dilaporkan dapat menekan tumor necrosis factor (TNF)- $\alpha$ yang diinduksi neutrofil pada konsentrasi 0,1\% (Cassia, 2013). Selain itu, Citral dapat menghambat induksi nitric oxide synthase (iNOS), produksi nitric oxide (NO) dan jalur lain yang diinduksi lipopolisakarida (LPS), dan menghambat peradangan jaringan secara oral dan topikal (80-90\%) (Oladeji, 2019).

\section{SIMPULAN}

Serai bermanfaat sebagai terapi komplementer terhadap pengobatan selulitis dikarenakan sifat antibakteri dan antiinflamasinya dari kandungan fenolik seperti tannin dan flavonoid, serta minyak atsiri yang mengandung citral, neral, geranial, dan lainnya.

\section{DAFTAR PUSTAKA}

Borschitz, T., Schlicht, S., Siegel, E., Hanke, E., Stebut V. (2015). Improvement of a clinical score for necrotizing fasciitis: 'Pain out of proportion' and high CRP levels aid the diagnosis. PLoS One ; 10 : e0132775.

Barbosa, L.C., Pereira, U.A., Martinazzo, A.P., Maltha, C.R.. (2008). Evaluation of the chemical composition of Brazilian commercial Cymbopogon citratus (DC) Stapf. samples. Molecules, 27;13(8):186 4-74,

Bennett JE. Dolin R. Blaser MJ. Mandell GL. Mandell, Douglas, and Bennett's principles and practice of infectious diseases. 7th. Philadelphia:: Churchill Livingstone/Elsevier; 2010.

Cássia, $\quad$ R. D., $\quad$ Silveira, L. N., Andrade, D. P. (2013). Review on antiinflammatory activity of monoterpenes. Molecules, 18 pp. 1227-1254

Concheiro, J., Loureiro, M., GonzálezVilas, D., et al. (2009). Erysipelas and cellulitis: a retrospective study of 122 cases. 100(10): 88894

Costa, G., Ferreira, J. P., Vitorino, C., Pina, M. E., Sousa, J. J., Figueiredo, I. V., \& Batista, M. T. (2016). Polyphenols from Cymbopogon citratus leaves as topical anti-inflammatory agents. Journal of Ethnopharmacology, 178, $\quad 222-$ 228. doi:10.1016/j.jep.2015.12.01 6

Hammer, K. A., Carson, C. F. Riley, T. V. (1999). Antimicrobial activity of essential oils and other plant extracts. Journal Applied Microbiology, 
Lipworth, A. D., Saavedra, A. P., Weinberg, A. N. and Johnson, R. A. (2012). Non-Necrotizing Infection of the Dermis and Subcutaneous Fat: Cellulitis and Erysipelas. $\quad$ Fitzpatrick's Dermatology In General Medicine. 8th ed. USA: McGrawHill. p.2160-9.

McNamara, D. R., Tleyjeh, I. M., Berbari, E. F., Lahr, B. D., Martinez, J. W., Mirzoyev, S.A., Baddour, L.M. (2007). Incidence of lower-extremity cellulitis: a population-based study in Olmsted county, Minnesota. Mayo Clin. Proc. Jul;82(7):817-2186,985-990,

Mbosso, E.J.T., Nogoela S., Nguedia, J. C. A., Beng V. P.; Rohmer M., Tsamo E. (2010). In vitro antimicrobial activity of extracts and compounds of some selected medicinal plants from Cameroon. Journal of Ethnopharmacology, 128, 476481.

Naik, M. I., Fomda, A. B, Jaykumar, E., AhmadBhat, J. (2010). Antibacterial activity of lemongrass (Cymbopogon citratus) oil against some selected pathogenic bacterias. Asian pasific journal of tropical medicine. Volume 3, Issue 7, Pages 535-538 https://doi.org/10.1016/S19957645(10)60129-0

Oladeji, O. S., Adelowo, F. E. and Ayodele, D. T. et al. (2019). Phytochemistry and pharmacological activities of Cymbopogon citratus: A review / Scientific African 6 doii 10.1016/j.sciaf.2019.e00137
Raff, A. B., \& Kroshinsky, D. (2016). Cellulitis. JAMA, 316(3), 325. doi:10.1001/jama.2016.8825

Rauber, C. S., Guterres, S. S., Schapoval, E.E. (2005). LC determination of citral in Cymbopogon citratus volatile oil. J Pharm Biomed Anal. Mar 9; 37(3):597-601.

Stevens D. L., Bisno, A. L., Chambers, H. F., et al. (2014). Infectious Diseases Society of America. Practice guidelines for the diagnosis and management of skin and soft tissue infections: 2014 update by the Infectious Diseases Society of America. Clin Infect Dis.; 59(2):e10-e52. doi:10.1093/cid/ciu296.

Shah, G., Richa, S., Vivek, P., Narender S., Bharpur S., and Mann A. S. (2011). Scientific basis for the therapeutic use of Cymbopogon citratus, stapf (Lemon grass) $\underline{J}$ Adv Pharm Technol Res. 2011 Jan-Mar; 2(1): 3-8. doi: $\underline{10.4103 / 2231-4040.79796}$

Silva, B. C. J. , Jung, W. G., Sabrina, $\underline{\text { Hossain, }} \underline{\text { S. H., Wimalasena }}, \underline{H}$. N. Pathirana, and Gang-Joon, $\mathrm{H}$. (2017). Antimicrobial property of lemongrass (Cymbopogon citratus) oil against pathogenic bacteria isolated from pet turtles. Lab Anim Res. 2017 Jun; 33(2): 84-91. doi: $\underline{10.5625 / \mathrm{lar} .2017 .33 .2 .84}$

Sullivan, T., \& de Barra, E. (2018). Diagnosis and management of cellulitis. Clinical Medicine, 18(2), 160163. doi:10.7861/clinmedicine.182-160 
Soares, M. O., Alves, R. C., Pires, C. Oliveira, M. B. Vinha Angolan, A. F. (2013). Cymbopogon citratus used for therapeutic benefits: nutritional composition and influence of solvents in phytochemicals content and antioxidant activity of leaf extracts Food Chem. Toxicol., 60 pp. 413-418

Tajidin, N. E., Ahmad, S. H. , Rosenani, A. B., Azimah, H., Munirah, M. . (2012). Chemical composition and citral content in lemongrass
(Cymbopogon citratus) essential oil at three maturity stages Afr. J. Biotechn., 11 (11) pp. 2685-269

Wolff, K., Johnson, R. A., Fitspatricks. (2008). Color atlas and synopsis of clinically dermatology. New York: McGrawHill. 